\title{
Lembaga Olah Seni Budaya Jambi Kota Seberang Mengenal Kompangan Dan Hadrah Sebagai Seni Tradisional Melayu Jambi 1995-2017
}

\author{
Siti Heidi Karmela ${ }^{1^{*}}$, Ferry Yanto $^{2}$, Malynda Ayu Aprilia ${ }^{3}$ \\ 1,2,3 Prgram Studi Pendidikan Sejarah, FKIP UNBARI \\ *Correspondence email: karmeladinanti@gmail.com
}

\begin{abstract}
This research is a historical study with the theme of cultural history, with the object of research being the Kompangan Group and the Hadrah Group belonging to the Jambi seberang cultural arts institute in Jelmu village, Kampung Tengah Sekoja district. The main research problem is about "Kompangan and Hadrah Group Managed by LOSBJKS in Jelmu Village Since 1995 - 2017", with two formulation of the problem proposed, namely; why LOSBJKS as an art institution can advance and develop the arts of Kompangan and Hadrah especially in Jelmu village and generally in the Sekoja area, and how LOSBJKS in preserving the values contained in the art of Kompangan and Hadrah as Jambi Malay traditional arts. The research objective is to explain the development of the Kompangan and Hadrah Groups belonging LOSBJKS which are the pioneers for the emergence of other traditional art groups especially in Jelmu village and generally in Sekoja area. In addition, it can also describe the roles and contributions of the board and members who are members of LOSBJKS to preserve the arts of Kompangan and Hadrah as traditional Jambi Malay arts. The research method used is the historical method which is method in historical research, where according to Kuntowijoyo the method starts from the heuristic, criticism, interpretation, and historiography. The findings show that there are change and developments from LOSBJKS, namely, first it can be seen from the name change from Riyadusholihin to LOSBJKS. Second, it is seen in the wider area of origin of permanent and non-permanent members. Third, in the terms of musical instruments, fourth, namely the costumes used especially the members of the Hadrah Group. Fifth, there was a change in the Kompangan technique (straight and circular patterns), if previously it was more characteristic of the Palembang (irregular) hitting technique, it had changed to Jambi striking technique that was more polite and neat. Sixth, in therm of singing there has also been a change, namely generally prayer and Malay songs, but at festivals sometimes there are also local songs so that they are not monoton.
\end{abstract}

Keywords: Kompangan Group; Hadrah; LOSBJKS; Traditional Art; Jambi Malay

\section{PENDAHULUAN}

Seni merupakan salah satu kebutuhan hidup manusia yaitu kebutuhan integratif selain kebutuhan biologis dan kebutuhan sosial. Kebutuhan integratif pada dasarnya melengkapi kebutuhan biologis dan kebutuhan sosial yang melekat pada setiap manusia secara universal. Kebutuhan integratif lazim juga disebut sebagai kebutuhan simbolik. Kebutuhan ini merepresentasikan bahwa manusia adalah makhluk budaya yang terpancar dari sifat-sifat dasar manusia sebagai makhluk pemikir, bermoral, dan bercita rasa. Kebutuhan integratif berfungsi untuk mengintegrasikan berbagai kebutuhan menjadi suatu sistem yang dibenarkan secara moral, dipahami akal pikiran, dan diterima cita rasa (R. Redfield, 1985).

Kesenian merupakan kebutuhan integratif manusia dalam rangka meningkatkan dan melangsungkan taraf hidup. Betapapun sederhana kehidupan manusia, di selasela memenuhi kebutuhan biologis atau kebutuhan primer senantiasa mencari peluang untuk mengungkapkan dan memanfaatkan keindahan melalui kesenian. Demikian pula keberadaan kesenian tradisional yang ada dan berkembang, dibakukan melalui tradisi-tradisi suatu masyarakat, serta untuk menopang dan mempertahankan kolektivitas sosial (Agus Maladi Irianto, 2005).

Begitu juga halnya dengan penduduk Melayu yang tinggal di Kawasan Sekoja yang memiliki kesenian tradisional yang memadukan suara, nyanyian, dan musik seperti kompangan dan hadrah, salah satunya ada di Kelurahan Jelmu Kecamatan Pelayangan. Group kompangan dan hadrah yang tetap eksis sejak dibentuk salah satunya adalah milik LOSBJKS. Mereka telah lama memiliki keterikatan melalui persepsi dan respons terhadap keberadaan kesenian tradisional tersebut. Persepsi dan respons masyarakat pendukung terhadap keberadaan kesenian tradisional tersebut pada dasarnya dipahami sebagai bentuk penyikapan, gagasan-gagasan, dan pemberian makna berdasarkan seluruh pengetahuan yang mereka miliki (Agus Maladi Irianto, 2005).

Eksistensi kesenian tradisional yang selama ini dianggap identitas kultural bagi masyarakat pendukungnya (Agus Maladi Irianto, 2010). Kesenian tradisional yang selama ini menjadi ekspresi masyarakat pendukung untuk menciptakan keserasian antara manusia dan lingkungannya, harus dituntut bersaing dengan produk-produk budaya lain secara terbuka. Oleh karena itu perlu kiranya peran dan kontribusi dari penduduk untuk menjaga eksistensi kesenian tradisional. Sama halnya dengan penduduk di Kelurahan Jelmu di Kawasan Sekoja yang juga tetap menjaga kelestarian kompangan dan hadrah agar tetap bertahan dan dikenal dengan mengikuti berbagai event-event penting untuk mempromosikannya agar dapat bersaing dengan kesenian tradisional yang lainnya. 
Siti Heidi Karmela et al, Lembaga Olah Seni Budaya Jambi Kota Seberang Mengenal Kompangan Dan Hadrah Sebagai Seni Tradisional Melayu Jambi 1995-2017

\section{METODE}

Metode penelitian yang digunakan adalah metode sejarah yang merupakan metode dalam penelitian historis, dimana menurut Kuntowijoyo metode tersebut dimulai dari tahapan heuristik, kritik, interpretasi, dan historiografi (Kuntowijoyo, 1995). Tahap pertama yang dilakukan adalah mencari dan mengumpulkan semua sumber-sumber sejarah yang mendukung penelitian baik itu sumber tertulis, sumber lisan, dan sumber benda (artefak / fisik). Sumber tertulis yang dimaksud lebih kepada arsip / dokumen milik LOSBJKS seperti akte pendirian, piagam penghargaan, foto-foto sebagai dokumentasi tentang kegiatan dan prestasi group kompangan dan hadrah di berbagai event. Namun sumber tertulis lainnya juga didapat informasi tambahannya dari buku, jurnal, skripsi, tesis. Untuk sumber lisan akan diwawancarai langsung pelaku dari penelitian ini yaitu pendiri dan pengurus, serta anggota group kompangan dan hadrah yang tergabung dalam LOSBJKS, anggota group kompangan Riyadusholihin, pemilik dan pengurus group kompangan dan group hadrah lainnya di Sekoja, tokoh adat, penduduk setempat, pegawai taman budaya Jambi dan Budaya Pariwisata Provinsi Jambi.

Pada tahap kritik akan dilakukan verifikasi sumber mana yang jenisnya primer dan mana yang sekunder. Tidak hanya itu saja, penulis akan melakukan kritik intern dan kritik ekstern terhadap sumber yang akan digunakan terutama arsip. Hal yang dilakukan saat kritik ekstern adalah melakukan identifikasi sumber dari bentuk / tampilan fisiknya untuk mengetahui kapan ditulis karena diyakini makin tua arsip maka nilai historisnya makin tinggi sehingga keasliannya (otensitas) juga teruji. Sementara itu kritik intern adalah dengan membaca kembali sumber untuk mengetahui kredibilitas dari informasi yang terkandung didalamya agar sesuai dengan penelitian yang akan dilakukan.

Ketika sampai pada tahap interpretasi, maka penulis akan menafsirkan dan merangkaikan fakta-fakta sejarah yang ada dari sumber yang digunakan tadi agar semua sumber saling berkaitan dan saling berhubungan satu dengan yang lainnya. Dengan kata lain penulis akan melakukan analisis (menguraikan) dan sintesis (menyatukan). Bahkan pada tahap ini penulis akan membayangkan bagaimana peristiwa yang akan diteliti ini terjadi di masa lalu dengan semua aspek pendukungnya, namun bukan berkhayal ataupun sekedar berimajinasi saja.

Tahap terakhir adalah dengan menuliskan rangkaian cerita atau kisah sejarah dari semua fakta sejarah yang ada berdasarkan penelitian yang diteliti secara berurutan dan kronologis peristiwa-peristiwa yang terjadi agar tidak menimbulkan keraguan atau kebingungan bagi pihak lain saat membacanya. Pada akhirnya penelitian ini akan menjadi karya sejarah berbentuk skripsi sejarah yang bertemakan sejarah kebudayaan khususnya tentang seni kompangan dan hadrah khususnya dibawah pengelolaan LOSBJKS di Kelurahan Jelmu, dan di kawasan Sekoja umumnya.

\section{HASIL DAN PEMBAHASAN Group Kompangan dan Group Hadrah LOSBJKS}

Salah satu kepedulian penduduk di kawasan sekoja terhadap kesenian kompangan dan hadrah adalah dengan mendirikan group keseniannya, termasuk Lembaga Olah Seni Budaya Jambi Kota Seberang (LOSBJKS) yang didirikan tahun 2006 oleh penduduk lokal. Adapun pendirinya yaitu Rawiyan, Ahmad Darmadi, Imron Rosadi, dan Adi Hidayat, mereka ada yang berasal dari Kelurahan Jelmu dan Kelurahan Kampung Tengah di Kecamatan Pelayangan. Jika dilihat dari latar belakang pekerjaannya, mereka ini ada yang PNS, karyawan swasta, dan wiraswasta namun tetap punya keinginan untuk melestarikan kesenian kompangan dan hadrah sebagai kesenian tradisional Melayu Jambi. LOSBJKS memiliki 3 (tiga) tujuan ; pertama, menggali dan mengembangkan seni dan budaya daerah pada umumnya, terutama daerah Kota Jambi. Kedua, menciptakan wadah dan menghimpun dan mengembangkan kreativitas pekerja seni. Ketiga, turut serta membantu pemerintah dalam memajukan seni dan budaya daerah khususnya daerah Jambi (Akte Notaris LOSBJKS, 2006).

Namun sebenarnya LOSBJKS ini awalnya dilatarbelakangi dulu dengan terbentuknya Group Kompangan Riyadusholihin yang beranggotakan remaja masjid Riyadusholihin yang telah lama aktif sejak 1980an - 1990an, dan banyak mengikuti dan memenangkan festival - festival kompangan yang banyak diselenggarakan institusi pemerintah seperti Dinas Kebudayaan dan Pariwisata Provinsi Jambi dan Taman Budaya Jambi. Kata Riyadusholihin sendiri berarti "istana orang-orang sholeh" diambil dari kitab hadis yg ditulis oleh imam besar Kyai Haji Madjid Rofar seorang ahli ilmu falak (perjalanan matahari) untuk menentukan jadwal shalat.

Anggota Group Kompangan Riyadusholihin ini terdiri dari anak-anak (SD-SMP) dan remaja (SMAMahasiswa) yang disebut anggota aktif. Anak-anak menjadi penari Anggut-nya dan remaja yang menjadi pemukul kompangan, jika sudah dewasa biasanya mereka tidak lagi menjadi anggota dan hanya menjadi penonton saja. Saat itu keanggotaan Group Riyadusholihin ini semuanya berasal dari penduduk sekitar saja yang terus berganti anggotanya karena tergantung usia anggota kompangan (Wawancara dengan Irfan, Anggota Group Kompangan Riyadusholihin, Kelurahan Jelmu, Kecamatan Kampung Tengah).

Sebagai pendiri Group Kompangan Riyadusholihin sejak awal, Rawiyan mengatakan bahwa orang-orang tua di Jelmu ingin agar anak-anak / kelompok pemudanya memiliki kegiatan lain selain olahraga, yaitu di bidang seni musik tradisional agar mereka mengetahui dan tertarik dengan seni budaya di 
sekoja, dan dipilihlah untuk membentuk group kompangan karena yang sudah ada waktu itu hanya seni musik gambus di Arab Melayu (Wawancara dengan Rawiyan, Pendiri LOSBJKS, Kelurahan Jelmu, Kecamatan Pelayangan).

Group Kompangan Riyadusholihin berganti nama menjadi LOSBJKS tahun 2006 yang berbentuk sanggar seni budaya, perbedaan keduanya terletak pada aktivitas anggotanya. Jika Riyadusholihin khusus untuk group kompangan dan hadrah di Jelmu saja tidak dari luar sedangkan LOSBJKS sudah beragam aktivitas group seni tradisional lainnya mulai dari kompangan, hadrah, marawis, dan gambus, dan kesenian Melayu, shalawat, bahkan pencak silat. Mengenai struktur organisasi LOSBJKS ini terdiri atas struktur kelembagaannya (meliputi badan pendiri, badan pengurus, dan badan pembina / penasehat) dan kelengkapan kelembagaannya (rapat badan pendiri, rapat badan pengurus, dan rapat gabungan bandan pendiri dan badan pengurus). Untuk badan pendiri dalam LOSBJKS memiliki kekuasaan tertinggi, sedangkan badan pengurus terdiri atas ketua, wakil ketua, sekretaris, bendahara (Akte Notaris LOSBJKS, 2006).

Keanggotaan group kompangan dan group hadrah dalam LOSBJKS terbagi atas anggota tetap (pemuda Jelmu) dan anggota tidak tetap yang berasal dari berbagai kelurahan di Kecamatan Pelayangan dan Kecamatan Danau Teluk. Untuk kisaran umur dari anggota group kompangan terbagi atas anak-anak (8-14 tahun), remaja (14 - 20 tahun), hingga dewasa $(21-23$ tahun) semuanya laki-laki, sedangkan untuk group hadrah rata-rata umur anggotanya berkisar 14-23 tahun baik laki-laki maupun perempuan. Pada dasarnya sasaran dari anggota LOSBJKS terutama untuk group kompangan dan hadrah yang dikelolanya adalah; pertama, anak-anak muda baik dari kalangan pelajar maupun umum, kedua, generasi muda di luar desa setempat, ketiga, masyarakat umum.

Kegiatan group kompangan yang dikelola oleh LOSBJKS ini mulai dari latihan rutin seminggu sekali dan lebih intens (jika ada undangan tampil pada festival, kontes, pagelaran seni) dan acara pernikahan. Hal ini sejalan dengan usaha-usaha yang dilakukan LOSBJKS untuk mencapai maksud dan tujuan awal pendirian yaitu melakukan dna mengikuti kegiatan dibidang seni dan budaya terutama dalam pertunjukan dan pergelaran seni dan budaya. Sebaliknya kegiatan penampilan group hadrahnya lebih pada acara-acara keagamaan.

Prestasi Group Kompangan dan Hadrah yang dibina oleh LOSBJKS sejak pendirian terlihat dari diperolehnya juara-juara di berbagai festival dan pagelaran seni budaya yang diikuti. Adapun semua acara tersebut sudah ada yang bersakala lokal hingga nasional. Beberapa diantaranya yaitu;

1. Juara I Lomba Kompangan Festival Danau Teluk II Jambi tanggal 26-30 Desember 2014
2. Juara I kategori hadrah Festival Kompangan, Hadrah, dan Qasidah, Rebana Ke-1 Taman ACI Muaro Jambi tanggal 11 - 13 Agustus 2017

3. Juara III Lomba Kompang Gemilau Ramadhan Tribun Jambi tanggal 1 Juni 2017

4. Juara I Festival Hadrah Se-Kota Jambi Masjid AlMaghfiroh Kel. Lebak Bandung Kasubdin Binkesos Dinas KSPM Provinsi Jambi tahun 2000

5. Juara I Festival Kompangan Se-Kota Jambi Karang Taruna Panca Agustus 2004

6. Juara I Kemilau Ramadhan Lomba Festival Kompangan tanggal 5 Agustus 2012

7. Juara II Hadrah Pekan Pesona Budaya Jambi Tahun 2005

8. Juara III Festival Kompangan HUT TVRI Jambi Ke16 Tahun 2011

9. Juara II Festival Kompangan Gebyar Budaya Koran Media Rakyat Jambi tanggal 10 Mei 2010

10.Juara I Festival Kreasi Islam Group Kompangan PMJI Jambi April 2005

11.Tropi bergilir Lomba Hadrah/Kompangan Ketua DPRD Kota Jambi

12.Juara I Lomba Kompangan dan Hadrah Se-Kota Jambi tahun 2007

13.Terbaik I Lomba Hadrah Pekan Pesona Budaya Jambi Tahun 2004

14.Juara I Festival Hadrah Universitas Jambi Expo Tanggal 21-22 April 2008.

15.Juara III Kemilau Ramadhan 1434 H Festival Kompangan Tribun Jambi tanggal 25 Juli 2013

16.Juara III Festival Kompangan Jambi Expo Tahun 2015

Beberapa pagelaran seni yang pernah diikuti yaitu Pagelaran Riuh Budaya Tapian Batanghari Tahun 2000, Malam Keagungan Melayu selama 4 (empat) tahun berturut-turut tahun 2000 - 2004 yang berkolaborasi dengan alat musik tradisional lainnya. Group kompangan dan group hadrah LOSBJKS ini juga pernah tampil di acara pembukaan event MTQ tungkat Kota dan Provinsi Jambi. Bahkan mendapat kesempatan untuk ikut serta dalam penyambutan tamu-tamu kehormatan yang datang ke Jambi mulai dari Presiden, Wapres, Menteri, dan pejabat daerah (Gubernur dan Walikota).

Para pendiri LOSBJKS menuturkan bahwa beberapa kendala yang pernah ditemui di awal pendiriannya antara lain dari segi pendanaan untuk membeli alat musik utama kompangan dan hadrah, kostum anggotanya termasuk untuk para penarinya. Tidak hanya alat musik utama saja, namun juga untuk membeli alat musik tambahan dan peralatan serta pelengkap pendukung penampilan group kompangan dan group hadrah. Namun kendala tersebut pada akhirnya teratasi karena group kompangan dan group hadrah LOSBJKS menjuarai beberapa festival seni budaya yang hadiahnya juga ada yang dalam bentuk uang yang akan dimasukkan dalam kas LOSBJKS dan 
ditambah dengan adanya bantuan dana dari pemerintah, dalam hal ini adalah Dinas Kebudayaan dan Pariwisata Provinsi Jambi (Wawancara dengan Rawiyan, Pendiri LOSBJKS, Kelurahan Jelmu, Kecamatan Pelayangan).

Dari segi pembinaan anggota group kompangan dan group hadrah juga menjadi salah satu kendala karena butuh waktu tertentu untuk melatih anggota, ada yang cepat paham tapi terkadang ada juga yang lambat penguasaannya. Hal ini tentu saja tergantung pada kisaran umur anggota group kompangan dan group hadrah. Jika masih usia anak-anak susah untuk diajak serius sedangkan mulai usia remaja hingga dewasa lebih cepat paham. Upaya yang dilakukan adalah dengan sabar terus melatih mereka dan member motivasi agar mereka giat berlatih jika ingin pandai menabuh kompangan dan menari Tari Anggutnya. Selain itu juga ada kendala dalam hal memberikan pemahaman kepada pemuda dan penduduk di Sekoja tentang perlunya kesadaran untuk mengetahui, memainkan, dan mempromosikan kesenian tradisional Melayu Jambi ke daerah luar agar tidak punah (Wawancara dengan Ahmad Darmadi, Pendiri LOSBJKS, Jelmu, Kecamatan Pelayangan).

Tak hanya pemuda saja, penduduk Sekoja pun tak semuanya yang sadar untuk melestarikan kesenian ini, ada sikap yang acuh tak acuh, tidak perduli, apalagi mereka yang sama sekali tidak paham tentang seni. Hal ini tentu saja menyebabkan perkembangan seni kompangan dan hadrah khususnya di Sekoja mengalami situasu yang fluktuatif. Namun salah satu upaya yang dilakukan adalah dengan cara menjalin komunikasi dengan tokoh adat Sekoja untuk ikut mengajak penduduk perduli dengan seni kompangan dan hadrah.

Group kompangan dan hadrah yang dikelola LOSBJKS ini terus mengalami perubahan dan perkembangan sejak berdiri tahun 1995 hingga tahun 2006. Pertama terlihat dari pergantian nama dari Riyadusholihin menjadi LOSBJKS yang menandakan bahwa kegiatan seni musik tradisional Melayu Jambi tidak lagi hanya sebatas seni kompangan saja, melainkan sudah ada seni hadrah, marawis, gambus, kesenian Melayu, hingga pencak silat. Kedua, terlihat pada makin luasnya daerah asal dari anggota tetap dan tidak tetapnya. Jika masih dalam pengelolaan Riyadusholihin, anggota group kompangan dan group hadrahnya hanya sebatas remaja mesjid Riyadusholihin di Jelmu saja, namun setelah terbentuk LOSBJKS maka keanggotaannya juga ada yang berasal dari luar Jelmu seperti Kampung Tengah, Arab Melayu, dan Ulu Gedong.

Perubahan dan perkembangan ketiga yaitu dari segi alat musiknya, jika sebelumnya hanya ada satu ukuran alat kompangan saja, selanjutnya ukuran alat kompangan sudah bertambah mulai dari ukuran kecil, sedang, dan besar yang akan menghasilkan suara dan bunyi yang berbeda satu sama lain. Diketahui bahwa sebelumnya alat kompangan yang dibeli oleh LOSBJKS khususnya dari Jawa, biasanya memakai kerincingan di sebelah kiri dan kanannya, namun karena tidak mencirikan budaya Melayu Jambi maka alat kompangan akhirnya tidak lagi memakai yang ada kerincingannya terutama dalam setiap penampilannya. Tidak hanya itu saja dalam beberapa penampilannya di festival atau pagelaran seni, group kompangan LOSBJKS ada juga menggunakan alat musik tambahan seperti drum bass agar terlihat menarik dan semarak untuk menarik perhatian penonton (Wawamcara dengan Zainal dan Abid Anggota Tetap dan Anggota Tidak Tetap Group Kompangan LOSBJKS, Arab Melayu dan Olak Kemang, Kecamatan Pelayangan dan Kecamatan Danau Teluk).

Sementara itu untuk alat musik hadrah bahkan kadang ditambah dengan alat musik bantu seperti marwas, gendang melayu, dan accordion (Wawancara dengan Rd. Ruliandi, Anggota Tetap Group Hadrah LOSBJKS, Tanjung Pasir, Kecamatan Danau Teluk).

Perubahan keempat, yaitu pada kostum yang digunakan khusunya anggota group hadrahnya. Jika tampil pada acara hari besar Islam (Maulid Nabi, Isra Mira'j, buka bersama di bulan ramadhan, dan haul) memakai gamis serba putih dan kopiah hitam saja, namun jika diundang warga pada acara hajatan seperti sunatan dan cukuran mereka mengenakan baju melayu berwarna biru, merah, kuning, merah maroon dengan alasan agar bervariasi saja, tidak bosan dilihat, dan menambah semangat saat berlatih.

Kelima, terjadi perubahan dalam teknik pukulan kompangan (pola lurus dan melingkar), jika sebelumnya lebih mencirikan teknik pukulan Palembang (tidak beraturan) berubah menjadi teknik pukulan Jambi yang lebih santun dan rapi. Sebaliknya teknik tabuhan / pukulan alat musik hadrah tidak berubah tetap dengan pukulan yang disebut tang dan tum. Keenam, dari segi nyanyian juga mengalami perubahan yaitu umumnya shalawat dan lagu melayu namun saat festival terkadang ada juga melantunkan lagu-lagu daerah agar tidak monoton.

\section{Lembaga Olah Seni Budaya Jambi Seberang Dalam Pelestarian Nilai-Nilai Seni Kompangan dan Hadrah}

Eksistensi kesenian tradisional yang selama ini dianggap sebagai identitas kultural bagi masyarakat pendukungnya (Agus Irianto Maladi, dkk, 2015). Oleh karenanya, keberadaan Seni kompangan dan hadrah Melayu Jambi telah menjadi ciri masyarakat Jambi yang memang identik dengan Keislaman mereka. Hal ini diperkuat dari nyanyian shalawat yang dilantunkan dalam kesenian tersebut.

Namun eksistensi kompangan dan hadrah sebagai seni tradisional Melayu Jambi tersebut harus tetap dijaga keberlangsungannya agar tetap bertahan ditengah hadirnya kesenian modern lainnya. Kiranya diperlukan usaha sadar untuk mempertahankannya, salah satunya yang dilakukan oleh LOSBJKS adalah salah satu upaya untuk melestarikan dan mempertahankan tradisi beserta 
nilai-nilai budaya masyarakat setempat, yang saat ini sudah sangat jauh meninggalkan kekayaan budaya.

Ada hal menarik yang perlu dipertimbangkan berkaitan dengan keberadaan ini, bahwa LOSBJKS merupakan tempat berkumpulnya generasi muda yang melakukan aktivitas seni maupun beberapa aktivitas budaya lainnya. Seluruh aktivitas seni dan budaya tersebut secara disadari dan secara langsung ikut membawa dampak positif kepada generasi muda untuk memahami nilai budaya setempat dan ikut berperan aktif menjaga dan melestarikan nilai-nilai budya tersebut.

Kesenian tradisional Melayu Jambi kompangan dan hadrah yang dikelola oleh LOSBJKS ternyata memberikan dampak positif secara ekonomi terutama bagi pihak-pihak yang terlibat didalamnya mulai dari pendiri dan pengurus hingga anggotanya. Setidaknya diketahui informasi dari salah satu pendiri LOSBJKS bahwa sejak terlibat dalam seni kompangan dan hadrah ini, dirinya sering diminta untuk mengajarkan seni tradisional ini di beberapa sekolah di Kota Jambi hingga ke kabupaten yang ada di Provinsi Jambi terutama untuk mengisi kegiatan ekstrakurikuler. Hal ini tentu saja menyebabkan dirinya mendapat honor mengajar yang lumayan besar nominalnya dan dibayarkan setiap akhir semester. Sekolah yang dimaksud yaitu SMA N. 7, SMP N. 7, SMP N. 10, SD N.54, SD N. 44, dan MIN Darussalam Kota Jambi, sedangkan untuk Kabupaten Batanghari di MTS N. 2 dan di Kabupaten Muaro Jambi di MAN 2 (Wawancara dengan Rawiyan, op.cit).

Tidak hanya pendiri LOSBJKS saja yang mendapat keuntungan dari seni tradional ini, para anggota pun juga mendapatkan honor tampil / uang saku yang dibagi rata dengan anggota lainnya, seperti yang dijelaskan beberapa anggota tetap:

Sebenarnya bagi saya honor tampil / uang saku yang didapat memang tidak besar nominalnya, namun lumayan banyak jika banyak ikut tampil dalam acara festival, pagelaran seni, dan undangan hajatan pribadi warga. Jadi yang penting latihan yang rajin saja agar selalu diajak dan diikutsertakan jika ada event-event penting" (Wawancara dengan Irfan Badius Safar, Anggota Tetap Group Kompangan LOSBJKS, Kampung Tengah, Kecamatan Pelayangan).

Ada juga anggota group hadrah LOSBJKS yang menuturkan bahwa bagi dirinya mendapat honor tampil / uang saku sebenarnya digunakan untuk menambah uang jajan saja karena dirinya masih sekolah, jadi yang penting bisa tampil di tempat publik dan keramaian agar bisa dikenal orang. Lagipula bergabung dengan group kompangan LOSBJKS hanya bersifat sampingan agar mendapat teman yang banyak (Wawancara dengan Ahmad Firnando, Anggota Tidak Tetap Group Hadrah LOSBJKS, Tanjung Pasir, Kecamatan Danau Teluk).

Selain mendapat honor saat tampil di event-event penting, pemasukan LOSBJKS juga didapat dari undangan hajatan warga seperti acara pernikahan, cukuran dan khitanan yang juga akan dibagi ke pengurus dan anggota group kompangan dan group hadrah, setelah dikurangi dulu untuk kas LOSBJKS. Ketika dikonfirmasi ke beberapa pengurus LOSBJKS diketahui bahwa sebenarnya pembagian honor tampil / uang saku tersebut didasarkan pada kekeluargaan bukan karena bersifat komersil, tapi kita tahu yang penting para anggota dibayarkan tenaganya ketika sudah selesai tampil. Untuk besaran masing-masingnya memang tergantung pada honor yang diterima. Untuk mengisi event seperti festival dan pagelaran seni, maka jika menang juara I tentu akan lebih banyak dapat nominal uangnya, namun untuk hajatan warga tidak selalu sama besarannya karena tergantung pada yang punya hajatan (Wawancara dengan Ady Hidayat, Pendiri dan Pengurus LOSBJKS, Kampung Tengah, Kecamatan Pelayangan).

Eksistensi dan prestasi dari group kompangan dan group hadrah yang dikelola oleh LOSBJKS ternyata mendapat perhatian dari pemerintah daerah, dalam hal ini adalah Dinas Kebudayaan dan Pariwisata Provinsi Jambi yang pernah member bantuan dana pembinaan yang oleh pengurus dan pendiri LOSBJKS dibelikan alat-alat musik utama (kompangan dan hadrah), alat musik penunjang, peralatan, dan perlengkapan pendukung penampilan group kompangan dan hadrah serta penampilan kesenian tradisional Melayu Jambi lainnya seperti gambus, marawis, kesenian Melayu (nyanyian shalawat dan tarian tradisional), hingga pencak silat.

\section{SIMPULAN}

Kesenian tradisional umumnya menjadi identitas kultural bagi masyarakat pendukungnya, menjadi ciri khas suatu daerah dan penduduk lokal yang tumbuh dan berkembang dalam kehidupan mereka. Kesenian tradisional lahir dari ide, gagasan, dan pemikiran yang tertuang dalam kreativitas masyarakat pendukungnya dalam berbagai bentuk, bisa melalui tarian, musik, nyanyian, atau menggabungkan semuanya.

Begitu juga dengan seni kompangan dan hadrah yang dikelola oleh LOSBJKS telah membentuk group kompangan dan group hadrah yang telah banyak mengikuti dan menjuarai berbagai perlombaan dan kejuaraan di berbagai event penting. Hal ini menandakan bahwa LOSBJKS sejak awal telah bertujuan untuk melestarikan dan mempromosikan kompangan dan hadrah sebagai kesenian tradisional Melayu Jambi yang memang harus dipertahankan agar Orang Jambi tidak kehilangan identitas kemelayuannya.

Bergabungnya penduduk mulai dari anak-anak, remaja, hingga dewasa dalam LOSBJKS telah memunculkan kreativitas seni mereka disamping untuk menumbuhkan kesadaran dan kecintaan pada seni tradisional tersebut. Mereka dapat mengenal, mengetahui, dan memainkan berbagai alat musik tradisional di LOSBJKS, yang tidak hanya alat kompangan dan alat musik hadrah saja, melainkan juga alat musik tradisional lainnya seperti rebana, marawis 
Siti Heidi Karmela et al, Lembaga Olah Seni Budaya Jambi Kota Seberang Mengenal Kompangan Dan Hadrah Sebagai Seni Tradisional Melayu Jambi 1995-2017

dan gambus, berlatih tari tradisional, menyanyi lagu melayu, belajar melantunkan shalawat, hingga praktek pencak silat.
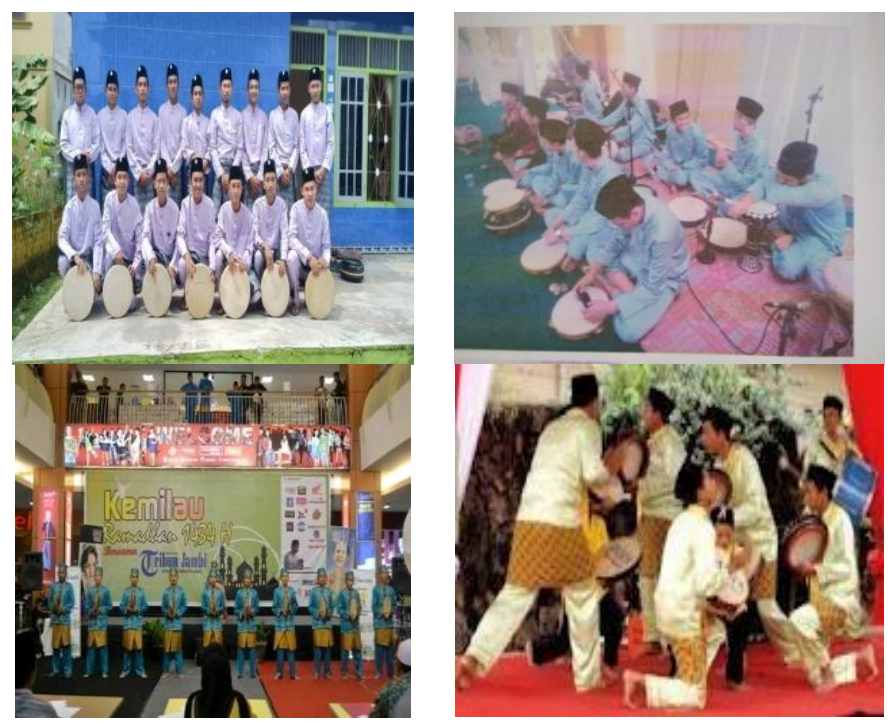

Gambar 1. Group Kompangan LOSBJKS
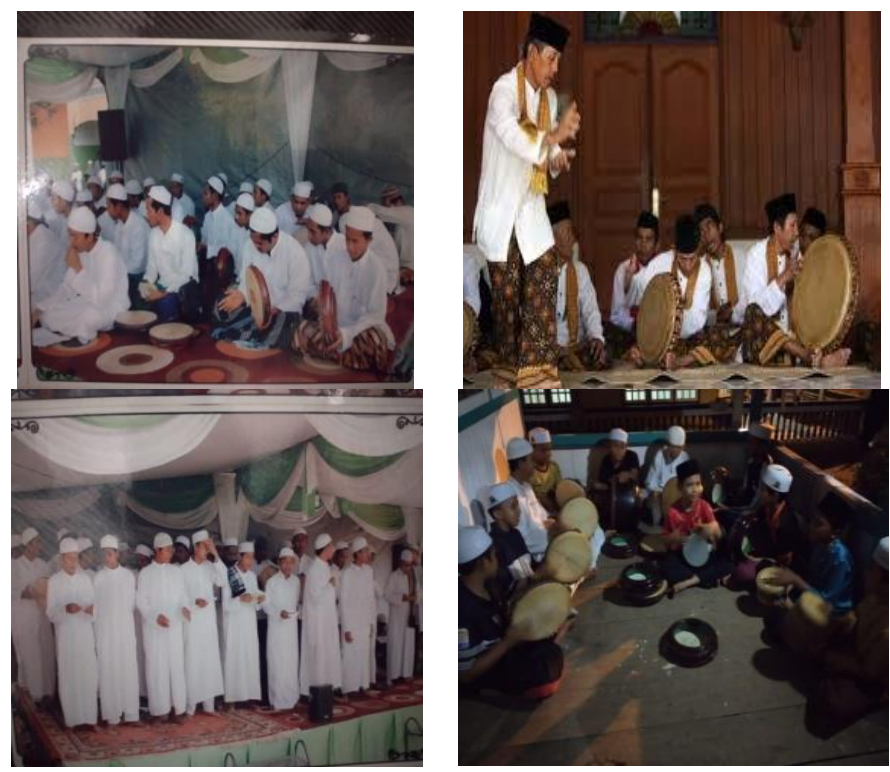

Gambar 2. Group Hadrah LOSBJKS
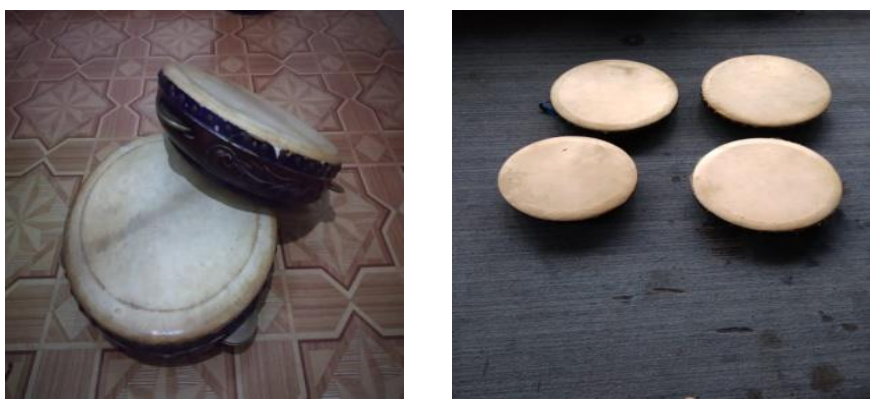
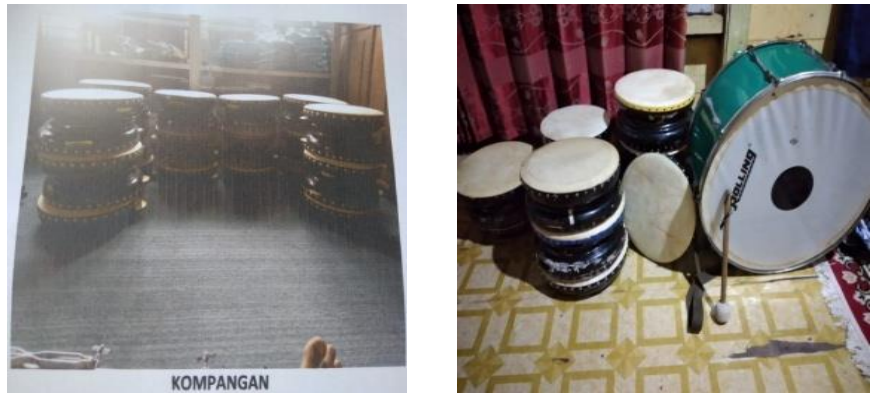

Gambar 3. Alat Musik Kompangan
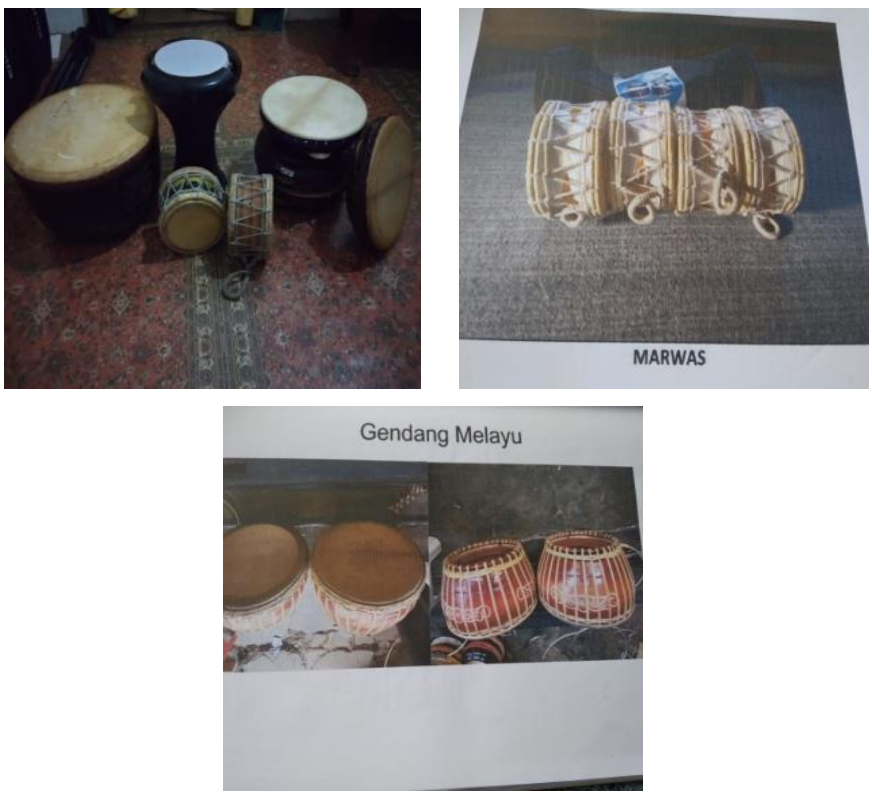

Gambar 4. Alat Musik Hadrah

\section{DAFTAR PUSTAKA}

Akte Notaris Lembaga Olah Seni Budaya Jambi Kota Seberang (LOSBJKS) No.4 Tahun Tanggal 21 Juni 2006.

Agus Maladi Irianto, 2005, Erotika Petani Jawa Memuja Dewi: Tayub, Antara Rutualitas dan Sensualitas, Semarang: Lengkongcilik Prees.

Agus Maladi Irianto, dkk, 2010, “Model-Model Pengembangan Atraksi Kesenian Tradisional Wonosobo Sebagai Strategi Pemahaman Wawasan Wisata Masyarakat Lokal", Laporan Penelitian, Semarang: LPPM Undip.

Agus Irianto Maladi, dkk, 2015, "Mengemas Kesenian Tradisional dalam Bentuk Industri Kreatif Studi Kasus Kesenian Tradisional”, Laporan Penelitian, Semarang: LPPM Undip.

Kuntowijiyo, 1995, Pengantar Ilmu Sejarah, Yogyakarta: Bentang.

R. Redfield, 1985, Masyarakat Petani dan Kebudayaan, (terj.,), Jakarta : YIIS. 